\title{
A Rare Presentation of Nodular Amyloidosis on the Lower Back
}

\author{
Yelena Dokic ${ }^{1}$, Paul Subrt ${ }^{2}$, Jaime Tschen ${ }^{3}$ \\ 1. Dermatology, Baylor College of Medicine, Houston, USA 2. Dermatology, Katy Westside Dermatology, Houston, USA \\ 3. Dermatology, St. Joseph Dermatopathology, Houston, USA
}

Corresponding author: Yelena Dokic, yelena.dokic@bcm.edu

\begin{abstract}
Primary localized cutaneous amyloidosis (PLCA) occurs when amyloid is deposited only within the skin and there is no evidence of systemic involvement. Nodular amyloidosis is the rarest subtype of PLCA. It typically involves the acral regions but can sometimes present on the head and neck. The condition usually presents clinically as a single tan or yellow nodule or plaque that may appear waxy. Herein, we present a rare case of a 66-year-old man with nodular amyloidosis on the lower back.
\end{abstract}

Categories: Dermatology

Keywords: primary localized cutaneous amyloidosis, nodular amyloidosis, lichen amyloidosis, papular amyloidosis

\section{Introduction}

Amyloidosis involves the deposition of amyloid protein into various tissues of the body. Primary localized cutaneous amyloidosis (PLCA) occurs when amyloid is deposited only within the skin, and there is no evidence of systemic involvement. Three subcategories exist within the PLCA category: macular, papular, and nodular amyloidosis. Nodular amyloidosis, or nodular localized cutaneous amyloidosis, is the rarest subtype of PLCA. Herein, we present a rare case of a 66-year-old man with nodular amyloidosis on the lower back, which had been present for several months at the time of presentation.

\section{Case Presentation}

A 66-year-old man presented with a yellowish, red plaque $(2 \mathrm{~cm}$ by $1 \mathrm{~cm})$, that arose on his back several months prior to presentation. No members of his family have had this condition. Additional history revealed that this patient had no trauma to the area and no history of dermatologic conditions. The patient's medical history was unremarkable. On examination, the patient was found to have a solitary yellowish, red plaque upon his back, $2 \mathrm{~cm}$ by $1 \mathrm{~cm}$ in size (Figure 1). No additional plaques or nodules were found anywhere upon the patient. The lesion had not received prior treatment. The remainder of the physical examination was unremarkable.

Received 09/23/2019

Review began 09/24/2019

Review ended 10/06/2019

Published 10/08/2019

(๑) Copyright 2019

Dokic et al. This is an open access article

distributed under the terms of the

Creative Commons Attribution License

CC-BY 3.0., which permits unrestricted

use, distribution, and reproduction in any

medium, provided the original author and source are credited. 


\section{Cureus}

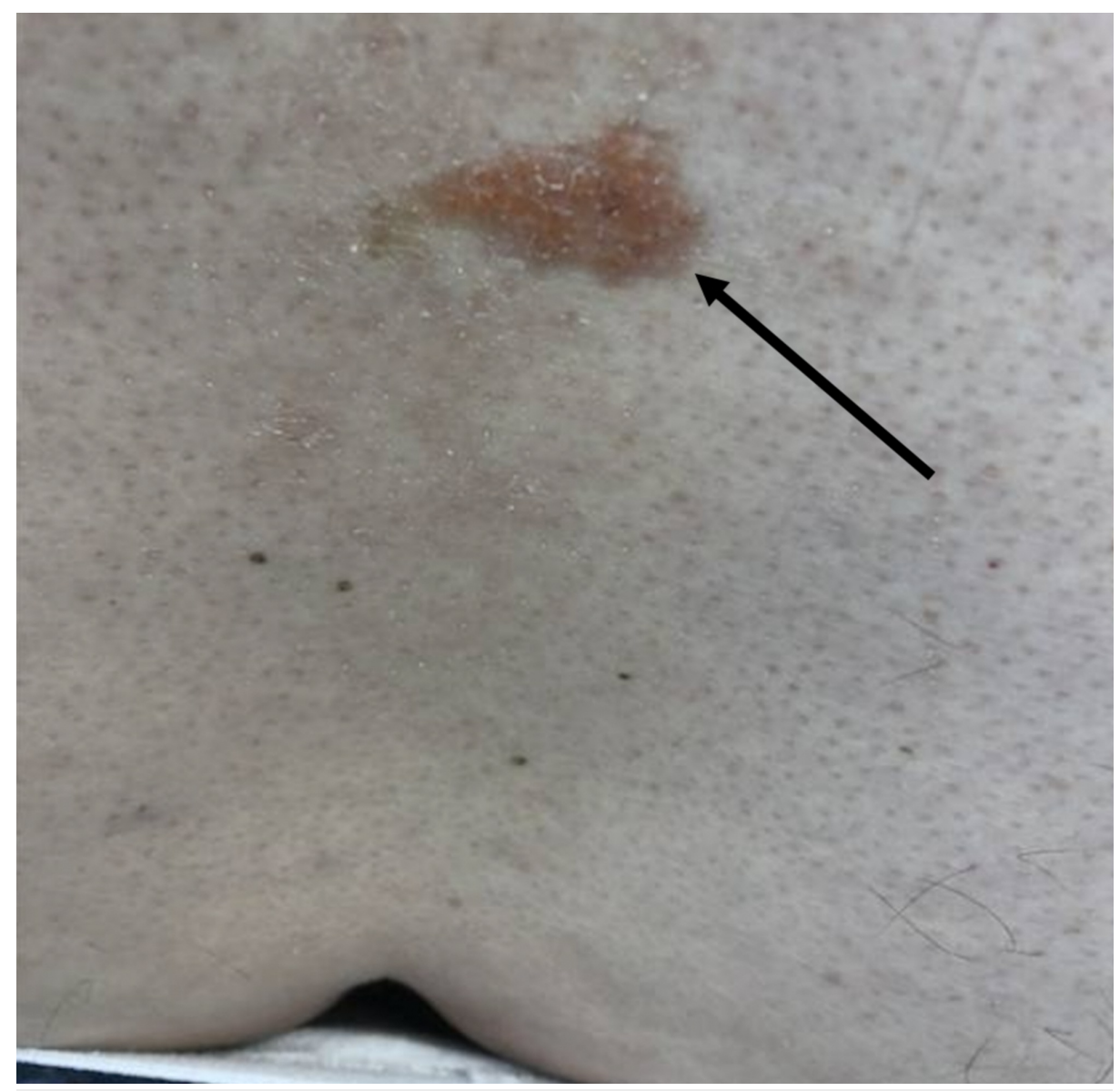

FIGURE 1: A yellowish-red plaque on the lower back.

Arrow indicates plaque, $2 \mathrm{~cm}$ by $1 \mathrm{~cm}$ in size.

A shave biopsy was performed, measuring 0.9 by $0.8 \mathrm{~cm}$, and histopathology revealed aggregates of homogenous eosinophilic material throughout the superficial and mid-dermis (Figure 2). Mild perivascular chronic inflammation with eosinophils and aggregates of plasma cells were also seen (Figures 3, 4). A special stain for crystal violet confirmed the material as amyloid. When stained with Congo red and viewed under polarized light, the sample demonstrated amyloid deposits with apple-green birefringence (Figures 5, 6). No keratin was found in the material on special stains with appropriate controls, supporting the extra epidermal origin of the amyloid. Thus, the amyloid deposition was most likely due to immunoglobulins produced either locally or systemically. 


\section{Cureus}

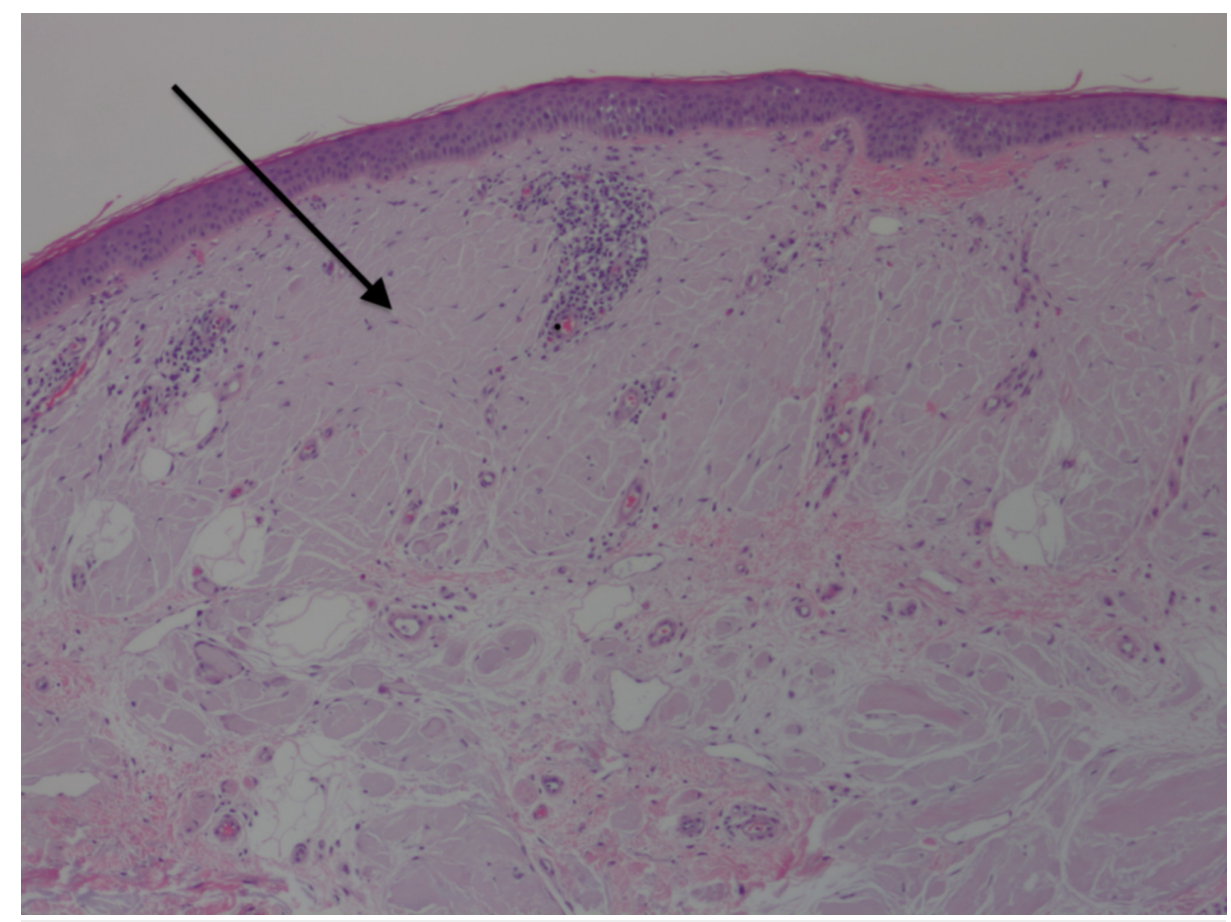

FIGURE 2: Homogenous amyloid material in the dermis.

Arrow indicates amyloid material.

Hematoxylin-eosin stain, original magnification 100x.

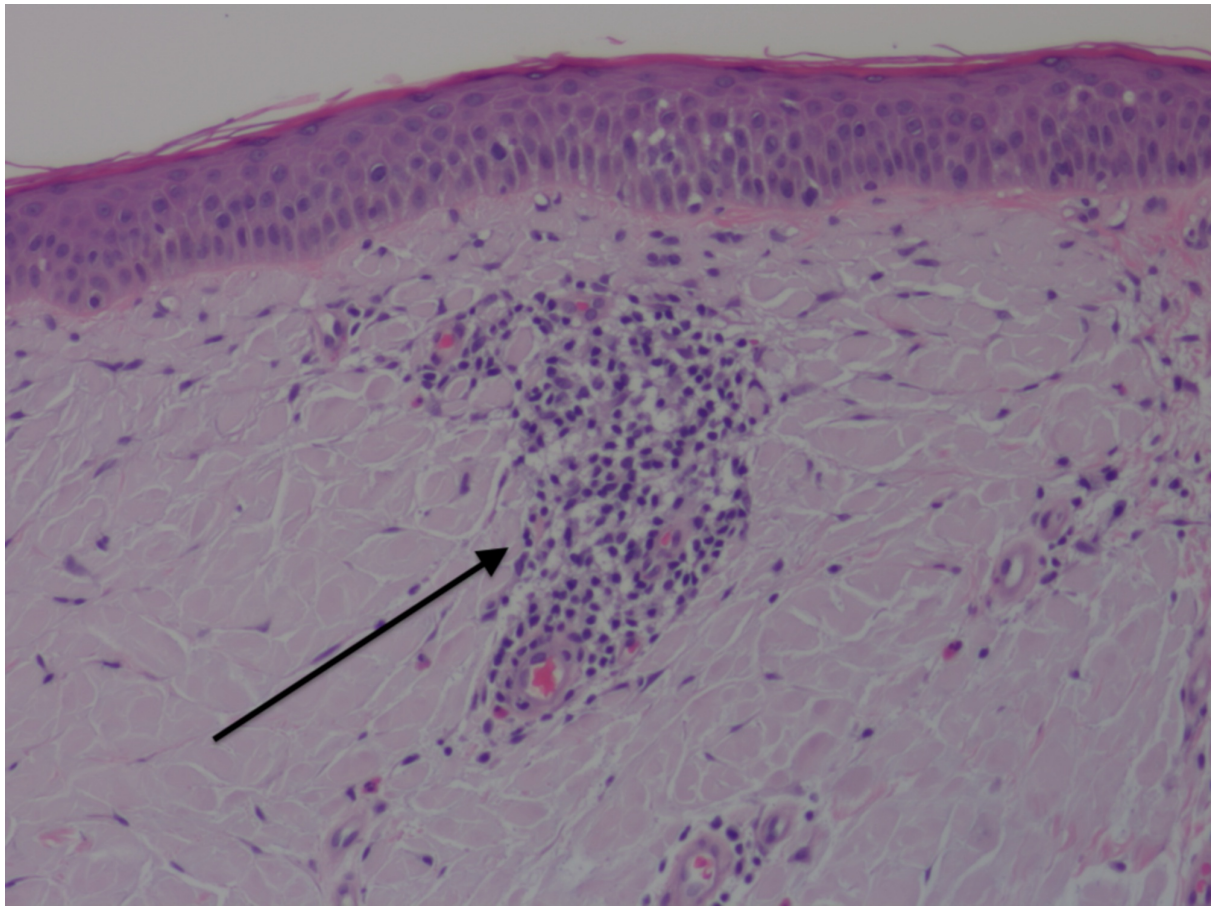

FIGURE 3: Clusters of perivascular mononuclear cells.

Arrow indicates perivascular mononuclear cells.

Hematoxylin-eosin stain, original magnification 200x. 


\section{Cureus}

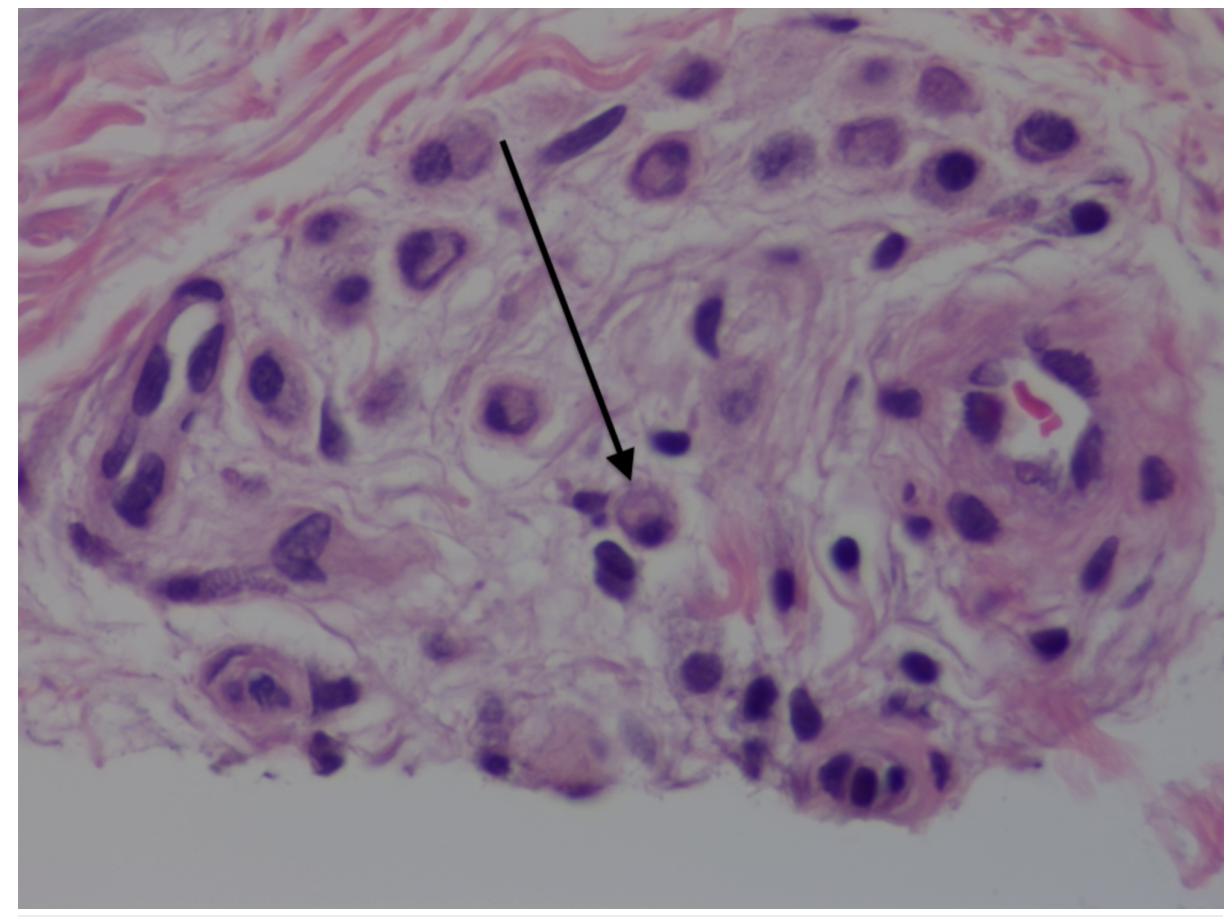

FIGURE 4: Clusters of perivascular mononuclear cells.

Arrow indicates a plasma cell with an eccentric nucleus.

Hematoxylin-eosin stain, original magnification 400x.

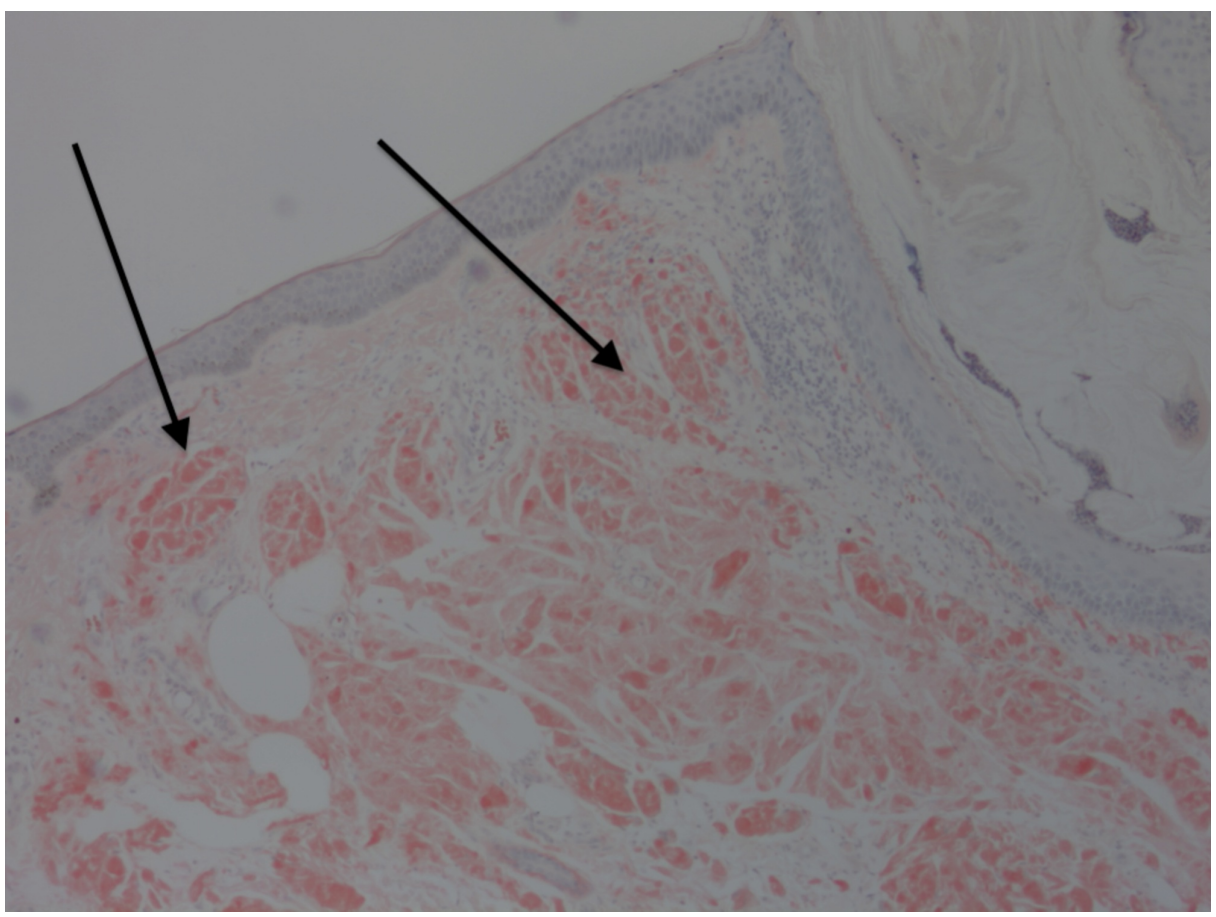

FIGURE 5: Amyloid material in the dermis.

Arrows pointing to amyloid material.

Positive Congo Red stain, original magnification 200x. 


\section{Cureus}

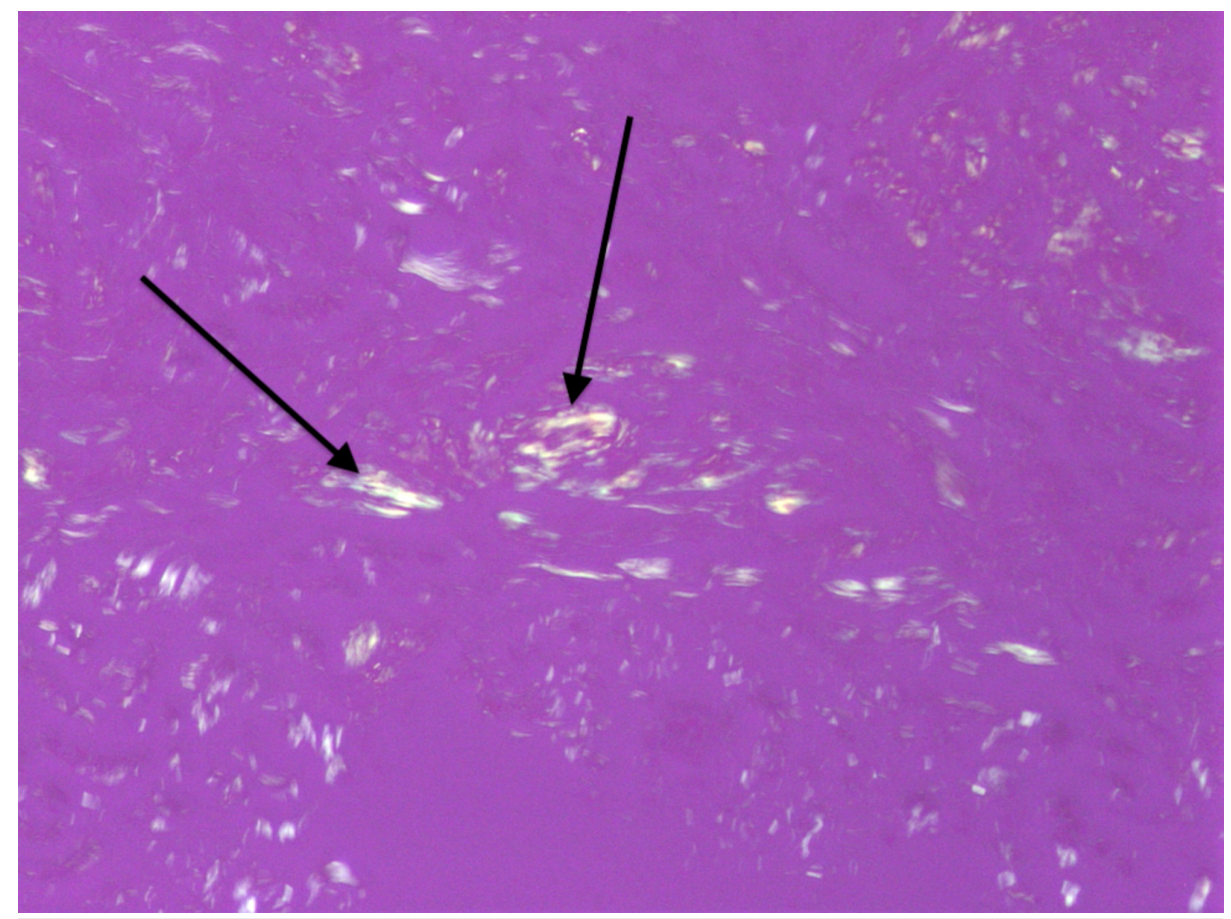

FIGURE 6: Amyloid deposits birefringent under polarized light.

Arrows indicate amyloid deposits.

Positive Congo Red stain with polarized light, original magnification 200x.

The patient underwent systemic evaluation, which consisted of comprehensive metabolic panel (Table 1), complete blood cell count (Table 2), serum protein electrophoresis (Table 3), urine protein electrophoresis (Table 4), Sjogren's antibodies (Table 5), rheumatoid arthritis factor (Table 6), and antinuclear antibodies (Table 7). Currently, the patient has a normal renal function, liver function, comprehensive metabolic panel, and complete blood cell count with differential. Serum and urine protein electrophoresis was negative. Sjogren's antibodies, rheumatoid arthritis factor, and antinuclear antibodies were negative. However, the patient was encouraged to undergo longitudinal follow up to monitor for potential progression to systemic disease. 


\section{Cureus}

\begin{tabular}{|c|c|c|c|}
\hline Comprehensive Metabolic Panel & Result & Units & Reference Interval \\
\hline Glucose & 87 & $\mathrm{mg} / \mathrm{dL}$ & $65-99$ \\
\hline BUN & 19 & $\mathrm{mg} / \mathrm{dL}$ & $8-27$ \\
\hline Creatinine & 1.23 & $\mathrm{mg} / \mathrm{dL}$ & $0.76-1.27$ \\
\hline eGFR if Non-African American & 61 & $\mathrm{~mL} / \mathrm{min} / 1.73$ & $>59$ \\
\hline eGFR if African American & 70 & $\mathrm{~mL} / \mathrm{min} / 1.73$ & $>59$ \\
\hline BUN/Creatinine Ratio & 15 & & $10-24$ \\
\hline Sodium & 141 & $\mathrm{mmol} / \mathrm{L}$ & 134-144 \\
\hline Potassium & 4.5 & $\mathrm{mmol} / \mathrm{L}$ & $3.5-5.2$ \\
\hline Chloride & 103 & $\mathrm{mmol} / \mathrm{L}$ & $96-106$ \\
\hline Carbon Dioxide, Total & 25 & $\mathrm{mmol} / \mathrm{L}$ & $20-29$ \\
\hline Calcium & 9.3 & $\mathrm{mg} / \mathrm{dL}$ & 8.6-10.2 \\
\hline Albumin & 4.1 & $\mathrm{~g} / \mathrm{dL}$ & $3.6-4.8$ \\
\hline Globulin, Total & 2.9 & $\mathrm{~g} / \mathrm{dL}$ & $1.5-4.5$ \\
\hline Albumin/Globulin Ratio & 1.4 & & $1.2-2.2$ \\
\hline Bilirubin, Total & 0.5 & $\mathrm{mg} / \mathrm{dL}$ & $0.0-1.2$ \\
\hline Alkaline Phosphatase & 63 & IU/L & 39-117 \\
\hline AST (SGOT) & 18 & $\mathrm{IU} / \mathrm{L}$ & $0-40$ \\
\hline ALT (SGPT) & 17 & $\mathrm{IU} / \mathrm{L}$ & $0-44$ \\
\hline
\end{tabular}

\section{TABLE 1: Comprehensive Metabolic Panel}

BUN = blood urea nitrogen, eGFR = estimated glomerular filtration rate, AST (SGOT) = aspartate aminotransferase (serum glutamic-oxaloacetic transaminase), ALT (SGPT) = alanine aminotransferase (serum glutamic-pyruvic transaminase) 


\section{Cureus}

\begin{tabular}{|c|c|c|c|}
\hline Complete Blood Count (CBC) with Differential/Platelet & Result & Units & Reference Interval \\
\hline WBC & 7.3 & X10E3/uL & 3.4-10.8 \\
\hline RBC & 4.83 & $\mathrm{X} 10 \mathrm{E} 3 / \mathrm{uL}$ & $4.14-5.80$ \\
\hline Hemoglobin & 15.0 & $\mathrm{~g} / \mathrm{dL}$ & 13.0-17.7 \\
\hline Hematocrit & 43.6 & $\%$ & $37.5-51.0$ \\
\hline MCV & 90 & $\mathrm{fL}$ & $79-97$ \\
\hline $\mathrm{MCH}$ & 31.1 & pg & 26.6-33.0 \\
\hline MCHC & 34.3 & $\mathrm{~g} / \mathrm{dL}$ & 31.5-35.7 \\
\hline RDW & 13.5 & $\%$ & 12.3-15.4 \\
\hline Platelets & 194 & X10E3/uL & $150-379$ \\
\hline Neutrophils & 61 & $\%$ & Not Estab. \\
\hline Lymphs & 22 & $\%$ & Not Estab. \\
\hline Monocytes & 11 & $\%$ & Not Estab. \\
\hline Eosinophils & 5 & $\%$ & Not Estab. \\
\hline Basophils & 1 & $\%$ & Not Estab. \\
\hline Neutrophils (Absolute) & 4.5 & X10E3/uL & $1.4-7.0$ \\
\hline Lymphocytes (Absolute) & 1.6 & X10E3/uL & $0.7-3.1$ \\
\hline Monocytes (Absolute) & 0.8 & X10E3/uL & $0.1-0.9$ \\
\hline Eosinophils (Absolute) & 0.4 & X10E3/uL & $0.0-0.4$ \\
\hline Basophils (Absolute) & 0.1 & X10E3/uL & $0.0-0.2$ \\
\hline Immature Granulocytes & 0 & $\%$ & Not Estab. \\
\hline Immature Granulocytes (Absolute) & 0.0 & X10E3/uL & $0.0-0.1$ \\
\hline
\end{tabular}

\section{TABLE 2: Complete Blood Count (CBC) with Differential/Platelet}

$\mathrm{WBC}=$ white blood cell count, $\mathrm{RBC}=$ red blood cell count, $\mathrm{MCV}=$ mean corpuscular volume, $\mathrm{MCH}=$ mean corpuscular hemoglobin, $\mathrm{MCHC}$ $=$ mean corpuscular hemoglobin concentration, $\mathrm{RDW}=$ red cell distribution width 


\section{Cureus}

\begin{tabular}{|c|c|c|c|}
\hline IFE, PE, and FLC, Serum & Result & Units & Reference Interval \\
\hline Immunoglobulin G, Quantitative, Serum & 1234 & $\mathrm{mg} / \mathrm{dL}$ & $700-1600$ \\
\hline Immunoglobulin A, Quantitative, Serum & 288 & $\mathrm{mg} / \mathrm{dL}$ & $61-437$ \\
\hline Immunoglobulin M, Quantitative, Serum & 168 & $\mathrm{mg} / \mathrm{dL}$ & 20-172 \\
\hline Protein, total & 7.0 & $\mathrm{~g} / \mathrm{dL}$ & $6.0-8.5$ \\
\hline Albumin & 3.7 & $\mathrm{~g} / \mathrm{dL}$ & $2.9-4.4$ \\
\hline Alpha-1-Globulin & 0.1 & g/dL & $0.0-0.4$ \\
\hline Alpha-2-Globulin & 0.7 & $\mathrm{~g} / \mathrm{dL}$ & 0.4-1.0 \\
\hline Beta Globulin & 1.1 & $\mathrm{~g} / \mathrm{dL}$ & $0.7-1.3$ \\
\hline Gamma Giobulin & 1.4 & $\mathrm{~g} / \mathrm{dL}$ & $0.4-1.8$ \\
\hline M (monoclonal) - Spike & Not Observed & $\mathrm{g} / \mathrm{dL}$ & Not Observed \\
\hline Globulin, Total & 3.3 & $\mathrm{~g} / \mathrm{dL}$ & $2.2-3.9$ \\
\hline Albumin/Globulin Ratio & 1.2 & & $0.7-1.7$ \\
\hline Free Kappa Light Chains, Serum & 17.5 & $\mathrm{mg} / \mathrm{L}$ & 3.3-19.4 \\
\hline Free Lambda Light Chains, Serum & 23.1 & $\mathrm{mg} / \mathrm{L}$ & $5.7-26.3$ \\
\hline Kappa/Lambda Ratio, Serum & 0.76 & & $0.26-1.65$ \\
\hline
\end{tabular}

\section{TABLE 3: IFE, PE, and FLC, Serum}

IFE = immunofixation blood test, PE = protein electrophoresis, FLC = quantitative free $\kappa$ (kappa) and $\lambda$ (lambda) light chains

\begin{tabular}{|c|c|c|c|}
\hline PE (Rfx, IFE), Random Urine & Result & Units & Reference Interval \\
\hline Protein, Total, Urine & 7.9 & $\mathrm{mg} / \mathrm{dL}$ & Not Estab. \\
\hline Albumin, Urine & 38.6 & $\%$ & \\
\hline Alpha-1-Globulin, Urine & 6.0 & $\%$ & \\
\hline Alpha-1-Globulin, Urine & 12.3 & $\%$ & \\
\hline Beta Globulin, Urine & 24.5 & $\%$ & \\
\hline Gamma Globulin, Urine & 18.4 & $\%$ & \\
\hline M (Monoclonal) - Spike, \% & Not Observed & $\%$ & Not Estab. \\
\hline \multicolumn{4}{|c|}{ TABLE 4: PE (Rfx, IFE), Random Urine } \\
\hline \multicolumn{4}{|c|}{ PE (Rfx, IFE) = protein electrophoresis with interpretation with reflex to IFE } \\
\hline
\end{tabular}




\section{Cureus}

\begin{tabular}{|l|l|l|l|}
\hline Sjogren's Antibodies, Anti-SS-A/-SS-B & Result & Units & Reference Interval \\
\hline Sjogren's Anti-SS-A & $<0.2$ & $\mathrm{Al}$ & $0.0-0.9$ \\
\hline Sjogren's Anti-SS-B & $<0.2$ & $\mathrm{Al}$ & $0.0-0.9$ \\
\hline
\end{tabular}

\section{TABLE 5: Sjogren's Antibodies}

Anti-SS-A = anti-Sjogren's syndrome-related antigen A, anti-SS-B = anti-Sjogren's syndrome-related antigen $\mathrm{B}, \mathrm{Al}=$ antibody index

\begin{tabular}{|c|c|c|c|}
\hline Rheumatoid Arthritis Factor & Result & Units & Reference Interval \\
\hline RA Latex Turbid. & $<10.0$ & $1 \mathrm{~J} / \mathrm{mL}$ & $0.0-13.9$ \\
\hline
\end{tabular}

TABLE 6: Rheumatoid Arthritis Factor

$\mathrm{RA}=$ rheumatoid arthritis

\begin{tabular}{|l|l|l|}
\hline \hline Antinuclear Antibodies Direct & Result & Units \\
\hline ANA Direct & Negative & Regative \\
\hline TABLE 7: Antinuclear Antibodies Direct & \\
\hline ANA = antinuclear antibody & \\
\hline
\end{tabular}

\section{Discussion}

Amyloid is an extracellular protein that appears microscopically as homogenous, amorphous, eosinophilic, and hyaline [1]. Amyloidosis comprises a collection of conditions in which amyloid proteins deposit into tissues of the body. If the amyloid is only deposited within the skin and there is no evidence of systemic involvement, then the condition is termed primary localized cutaneous amyloidosis. However, if the amyloid is systemic and involves several organs or tissues, then it is termed primary or secondary systemic amyloidosis [1].

Within the category of PLCA exists three subcategories: macular, papular, and nodular amyloidosis. Of these three subtypes, the nodular amyloidosis subtype, or PLCA, is the rarest. Gottron was the first to describe nodular amyloidosis. Clinically, PLCA appears as single or multiple nodules that are yellow, brown, or reddish. The nodules are about $0.5 \mathrm{~cm}$ to $7 \mathrm{~cm}$ in size and are typically present on acral surfaces of the body, trunk, neck, or extremities [2]. Occasionally, multiple nodules may sometimes be found in locations such as the face, scalp, or extremities. Nodular amyloidosis is rarely present on the back, but such is the case in our patient.

The mean age of onset of nodular localized cutaneous amyloidosis is 55 years, with a range of 33 to 86 years [3]. The condition does not show a predilection for men versus women, nor a particular race. Risk factors for the condition have not been established. In most cases, PLCA is benign and limited to the skin. However, it has been noted to progress to systemic disease in about $7 \%$ to $50 \%$ of patient cases [4]. Also, PLCA lesions may appear histologically similar to lesions found in primary and myeloma-associated systemic amyloidosis [5]. Several case reports have established links between PLCA and Sjogren's syndrome [6, 7]. In fact, PLCA has been found in $25 \%$ of patients with Sjogren's syndrome [6]. Thus, it has been deemed important for patients to undergo longitudinal follow up to monitor for potential progression to systemic disease. A systemic evaluation consists of complete blood cell count, comprehensive metabolic panel, urinalysis, serum, and urine protein electrophoresis [4].

The pathophysiology of PLCA involves the production of amyloid light chain (AL) fibril proteins by plasma cells. The AL proteins are composed of immunoglobulin light chains, which can also be found in other types of amyloidosis. Immunohistochemical stains have shown the AL proteins to be composed of either kappa or lambda immunoglobulins [8]. The monoclonal plasma cells secrete the AL fibrils in a mechanism that is still 
unknown, but unique to nodular amyloidosis [9]. The pathophysiology of other subtypes of amyloidosis, such as lichen and macular amyloidosis, involves the secretion of amyloid fibrils by keratinocytes [10].

Because of the extremely characteristic histopathology of amyloidosis, diagnosis is made by biopsy [3]. Histological examination of nodular amyloidosis reveals eosinophilic deposits distributed throughout the dermis. The overlying epidermis may reflect atrophic changes. The walls of small vessels may have amyloid deposits, and perivascular lymphocytes and plasma cells can be observed. This is unique to the nodular variant of amyloidosis. Of note, histopathology is unable to distinguish between localized and systemic amyloidosis. However, an increased amount of plasma cells scattered through the deposits is unique to the nodular amyloidosis subtype [11]. When the sample is stained with Congo red and viewed under polarized light, the amyloid deposits exhibit characteristic apple-green birefringence.

Various treatments for nodular cutaneous amyloidosis exist. The most common method is surgical removal, specifically using a surgical shave technique [3]. In cases of facial nodular amyloidosis, the surgical technique is highly preferred [12]. Other treatment methods include dermabrasion or electrodissection [13, 14]. Laser treatment, specifically with pulsed lasers or carbon dioxide, has also been proved to help patients in some cases [15]. A report of successful treatment with intralesional methotrexate has also been published [16]. Of note, nodular cutaneous amyloidosis lesions may recur even after treatment.

\section{Conclusions}

Nodular amyloidosis is a rare condition that is typically identified on the extremities; however, it can also be located on the lower back. It is important for patients with the condition to undergo a systemic evaluation to monitor for potential progression to systemic disease.

\section{Additional Information \\ Disclosures}

Human subjects: Consent was obtained by all participants in this study. Conflicts of interest: In compliance with the ICMJE uniform disclosure form, all authors declare the following: Payment/services info: All authors have declared that no financial support was received from any organization for the submitted work. Financial relationships: All authors have declared that they have no financial relationships at present or within the previous three years with any organizations that might have an interest in the submitted work. Other relationships: All authors have declared that there are no other relationships or activities that could appear to have influenced the submitted work.

\section{References}

1. Lee DY, Kim YJ, Lee JY, Kim MK, Yoon TY: Primary localized cutaneous nodular amyloidosis following local trauma. Ann Dermatol. 2011, 23:515-518. 10.5021/ad.2011.23.4.515

2. Brownstein MH, Helwig EB: The cutaneous amyloidoses. I. Localized forms. Arch Dermatol. 1970, 102:8-19.

3. Schipper C, Cornelissen A, Welters C, Hoogbergen M: Treatment of rare nodular amyloidosis on the nose: a case report. JPRAS Open. 2015, 6:25-30. 10.1016/j.jpra.2015.07.006

4. Kalajian AH, Waldman M, Knable AL: Nodular primary localized cutaneous amyloidosis after trauma: a case report and discussion of the rate of progression to systemic amyloidosis. J Am Acad Dermatol.. 2007, 57:S26-S29. 10.1016/j.jaad.2006.12.014

5. Breathnach SM: Amyloid and amyloidosis. J Am Acad Dermatol. 1988, 18:1-16. 10.1016/s01909622(88)70001-8

6. Wey SJ, Chen YM, Lai PJ, Chen DY: Primary sjogren syndrome manifested as localized cutaneous nodular amyloidosis. J Clin Rheumatol. 2011, 17:368-370. 10.1097/RHU.0b013e31823209ba

7. Moon AO, Calamia KT, Walsh JS: Nodular amyloidosis: review and long-term follow-up of 16 cases . Arch Dermatol. 2003, 139:1157-1159. 10.1001/archderm.139.9.1157

8. MacDonald DM, Black MM, Ramnarain N: Immunofluorescence studies in primary localized cutaneous amyloidosis. Br J Dermatol. 1977, 96:635-641. 10.1111/j.1365-2133.1977.tb05208.x

9. Setoguchi M, Hoshii Y, Kawano H, Ishihara T: Analysis of plasma cell clonality in localized AL amyloidosis . Amyloid. 2000, 7:41-45.

10. Apaydin R, Gurbuz Y, Bayramgurler D, Muezzinoglu B, Bilen N: Cytokeratin expression in lichen amyloidosus and macular amyloidosis. J Eur Acad Dermatol Venereol. 2004, 18:305-309. 10.1111/j.14683083.2004.00905.x

11. Kakani RS, Goldstein AE, Meisher I, Hoffman C: Nodular amyloidosis: case report and literature review . J Cutan Med Surg. 2001, 5:101-104. 10.1177/120347540100500201

12. Grattan CE, Burton JL, Dahl MG: Two cases of nodular cutaneous amyloid with positive organ-specific antibodies, treated by shave excision. Clin Exp Dermatol. 1988, 13:187-189. 10.1111/j.13652230.1988.tb01967.x

13. Woollons A, Black MM: Nodular localized primary cutaneous amyloidosis: a long-term follow-up study . Br J Dermatol. 2001, 145:105-109. 10.1046/j.1365-2133.2001.04291.x

14. Vestey JP, Tidman MJ, McLaren KM: Primary nodular cutaneous amyloidosis: long-term follow-up and treatment. Clin Exp Dermatol. 1994, 19:159-162. 10.1111/j.1365-2230.1994.tb01148.x

15. Al Yahya RS: Treatment of primary cutaneous amyloidosis with laser: a review of the literature . Lasers Med Sci. 2016, 31:1027-1035. 10.1007/s10103-016-1917-8

16. Raymond J, Choi J: Nodular cutaneous amyloidosis effectively treated with intralesional methotrexate. 


\section{Cureus}

JAAD Case Rep. 2016, 2:373-376. 10.1016/j.jdcr.2016.04.006 